\title{
PELAKSANAAN PELAYANAN TERBAIK 3S (SENYUM, SALAM, SAPA) PARA KARYAWAN MENINGKATKAN KEPUASAN PELANGGAN
}

\author{
Masayu Endang Apriyanti ${ }^{1)}$, Fitriyah Puspita ${ }^{2)}$ \\ Program Studi Desain Komunikasi Visual, Fakultas Bahasa Dan Seni \\ Program Studi Tekhnik Informatika, FakultasTekhnik dan MIPA \\ Universitas Indraprasta PGRI Jakarta \\ masayuendangapriyanti@gmail.com
}

\begin{abstract}
Abstrak
Pengabdian Masyarakat merupakan salah satu kewajiban tridharma sebagai seorang dosen, maka kali ini abdimas dilaksanakan di dua perusahaan yang bergerak dibidang usaha stasiun pengisian bahan bakar di daerah Bekasi. Melalui pengamatan kami, pada umumnya karyawan tidak memberikan pelayanan terbaiknya untuk setiap pelanggan, apalagi ketika situasi transaksi jual beli sedang berlangsung sangat ramai maka sering kali pelayanan terbaik tidak dilakukan atau sering terabaikan, padahal hal tersebut dapat mempengaruhi tingkat kepuasan yang didapatkan oleh pelanggan. Berdasarkan hal tersebut maka kami berinisiatif untuk memberikan pelatihan mengenai pelayanan terbaik 3S (Senyum, Salam, Sapa) untuk meningkatkan kepuasan pelanggan, dimana setelah pelatihan diharapkan setiap karyawan mampu memberikan pelayanan terbaiknya, karena hal tersebut maka tingkat kepuasan yang dirasakan pelanggan dapat maksimal, produktivitas kerja meningkat, omzet bertambah, eksistensi perusahaan semakin terjamin dan masa depan menjadi lebih baik, karena mereka telah paham secara mendalam mengenai pentingnya peran aktif karyawan dalam memberikan pelayanan terbaik dengan melaksanakan $3 \mathrm{~S}$ secara optimal.
\end{abstract}

Kata kunci : Pelaksanaan Pelayanan Terbaik, 3S (Senyum, Salam, Sapa), Kepuasan Pelanggan

\begin{abstract}
Community service performed is one of the obligations of tridharma Lecturer, so this time performed conducted at two company which is engaged in the business of general refueling stations located in Jati Asih, Bekasi. Throught our observations, in general, employees do not provide the best service for each customer, especially when the situation of buying and selling transactions in progress is very crowded then often the best service is not done or often ignored, even though it can affect the level of satisfaction obtained by customers. Based on that, so we took the initiative to provide training on the best service starting from $3 S$ concept (Smile, Regard, Greetings) to improve customer satisfaction, where after the training is expected every employee is able to provide the best service, because it can increase the level of customer satisfaction to the maximum, Productivity and Turnover increases, the existence of the company is increasingly assured so the future gets better, because finally they have understood deeply about the importance of active role of employees in providing the best service by implementing $3 S$ optimally.
\end{abstract}

Keywords : Implementation of the Best Service, $3 S$ (Smile, Regard, Greeting), Customer Satisfaction 


\section{PENDAHULUAN}

Perusahaan memiliki visi, misi, tujuan dan target yang berbeda, namun dengan tujuan yang sama yaitu mendapatkan pelanggan sebanyak mungkin untuk mempertahankan eksistensi kehidupan perusahaan agar mampu bertahan dalam persaingan yang ada. Dalam mempertahankan pelanggan, ada beragam cara atau strategi yang dapat dilakukan untuk mencapai target yang ditetapkan, dan salah satunya adalah mendapatkan kesetiaan pelanggan agar selalu membeli produk / jasa yang ditawarkan perusahaan kita, karena mendapatkan dan mempertahankan pelanggan bagi perusahaan bukanlah hal yang mudah apalagi di era persaingan global ini, dan kesetiaan pelanggan sangat dipengaruhi berbagai faktor, salah satunya adalah nilai kepuasan yang mereka dapatkan. Oleh karena itu, agar perusahaan tetap berada pada posisi yang kuat, dan dapat memenangkan persaingan usaha dan eksis terus dalam persaingan, maka pihak perusahaan harus kreatif menciptakan output atau menyediakan barang dan jasa yang variatif dengan kuantitas dan kualitas memadai dan tepat untuk memenuhi kebutuhan dan keinginan para konsumennya pada tingkat kepuasan yang terbaik yang didapatkan oleh konsumen.

Mencintai bisnis dan pelanggan dengan sepenuh hati, melayaninya dengan ikhlas dan berkualitas, carilah pelanggan-pelanggan yang terbaik, rawatlah dengan kualitas, hiduplah dari keuntungan yang mereka berikan (Djajendra, august1, 2017, service exelence). Sesungguhnya, pelayanan terbaik dapat meningkatkan pertumbuhan bisnis, dengan sistem yang efektif, kepemimpinan tegas dan kepribadian positif dalam keterampilan unggul, karena Setiap karyawan mampu mengetahui secara jelas akan hal terbaik dan tepat untuk dilakukan dalam pelayanan terbaiknya, sehingga tercipta hubungan emosional positif berkolaborasi kerja tanpa egois, sehingga pelangganpun merasa mendapatkan yang terbaik dari bisnis ini.

Dalam pelatihan ini akan dipresentasikan mengenai konsep 3S yang ditetapkan oleh perusahaan sesuai kebijakan yang berlaku yaitu 3S : Senyum, Salam, Sapa dimana 3S ini sejatinya memberikan makna yang mendalam dalam pelayanan terbaik, yaitu Setiap karyawan selalu tampil sehat secara fisik dan percaya diri secara mental membuat mereka tersenyum tulus ikhlas dari dalam diri tanpa paksaan sehingga senyum tersebut terlihat indah dan manis, sikap proaktif secara sosial, komunikatif serta teguh secara spiritual membuat karyawan dapat menebarkan salam keselamatan bagi semuanya, serta cerdas\&seimbang secara emosional membuat mereka menyapa semua pelanggan dengan ramah dan hangat sehingga dapat memberikan pelayanan pelanggan secara profesional dan berkualitas prima.

Perusahaan akan memberikan positive reinforcement (penguatan positif) atas semua hal positif yang dihasilkan karyawan, seperti perilaku bekerja keras, ramah kepada pelanggan, menekankan pada kualitas, dengan memberikan pujian, promosi jabatan, kepastian kerja, bonus atau kenaikan gaji (Eddy Soeryanto Soegoto, 2014 : 378-379). Artinya, tidak ada kebaikan dan prestasi yang sia-sia, apapun nilai positif yang dilakukan karyawan pasti akan berbuah kebaikan juga bagi karyawan tersebut.

Aspek pasar dan pemasaran menempati urutan pertama dalam study kelayakan dan merupakan pilar utama bagi rencana pendirian perusahaan (Robert Argene, 2003 : 147), dengan kata lain berarti kepuasan konsumen menjadi salah satu faktor yang harus diperhatikan dengan serius dan fokus agar perusahaan mampu berdiri kokoh, dan hal ini harus didukung penuh oleh karyawan dalam berinteraksi langsung kepada pelanggan. 
Perusahaan menerapkan program-program berkualitas prima dan pengembangan produktivitas yang bertujuan meningkatkan reputasi produk dan profitabilitas kegiatan operasi secara keseluruhan (Robert Anthony, 2005 : 371), berarti setiap perusahaan mengharapkan profit dari setiap operasional yang dilakukannya, karena dengan profit yang dihasilkan itulah perusahaan dapat lancar beroperasi, maka pelayanan yang baik dari karyawan dalam memuaskan pelanggan dapat menjadi salah satu peran penting yang berdampak positif dalam meningkatkan omzet dan profit yang didapat perusahaan.

Tujuan dari Organisasi adalah mendapatkan dan mempertahankan pelanggan $(\mathrm{Cy}$ Charney, 1998 : 115), karena sesungguhnya mempertahankan pelanggan bukan hanya menghasilkan output berkualitas, melainkan juga harus dapat memberikan kepuasan dalam pelayanannya, agar pelanggan tersebut setia / tidak tertarik membeli output pada pesaing/perusahaan lain, oleh karena hal itulah, perusahaan harus memiliki sumber daya manusia yang handal, berkualitas, solid, Mampu bersinergi dengan baik, memahami peran dan tugas masing-masing serta terus belajar mengembangkan kualitas diri agar dapat mendukung perusahaan dalam meraih tujuan dan target yang ditetapkan.

Dalam kegiatan seminar ini diharapkan mampu memberikan penjelasan yang detail secara konsep teoritis dan realita yang dapat diaplikasikan dalam pekerjaan, dapat memberikan motivasi, penanaman etika dan karakter yang baik untuk para karyawan, sehingga dapat mencetak karyawan yang memiliki sumber daya manusia yang handal, berkualitas dan bermanfaat bagi perusahaan, dan perusahaan mampu membina hubungan lebih baik lagi dengan semua strata didalam manajemennya, sehingga target, arah dan tujuan masa depan perusahaan lebih maju lagi dari berbagai sudut pandang.

Untuk organisasi nirlaba, penetapan kebijakan dapat meliputi pencapaian standard yang ditetapkan oleh undang-undang atau organisasi untuk memaksimalkan posisinya (Elwood S. Buffa, 2002 : 446), kalimat ini dapat disimpulkan, misalkan saja perusahaan yang unit kerjanya adalah SPBU, maka perusahaan harus selektif dalam merekrut stafstaf hebat untuk mengatur agar operasional perusahaan dapat berjalan dengan lancar, kondusif dan efektif, demikian juga pihak manajemen hanya merekrut operator yang jujur, ulet dan bekerja keras sehingga setoran yang mereka lakukan ontime dengan kejujuran yang tidak merugikan perusahaan serta dapat membina hubungan dengan baik terutama kepada pelanggan, dan semua itu akan sangat mempengaruhi eksistensi perusahaan agar dapat kuat bertahan memenangkan persaingan usaha yang ketat dan berdiri kokoh dalam jangka panjang dengan masa depan yang terarah dengan baik.

Dalam abdimas kali ini, kami kolaborasi dosen Prodi Desain Komunikasi Visual dan dosen Prodi Tekhnik Informatika berkontribusi memberikan inspirasi, motivasi dan pelatihan dasar untuk para karyawan di dua perusahaan tersebut, bahwa layanan terbaik, harus mampu melaksanakan konsep $3 \mathrm{~S}$ sepenuh hati tulus dan ikhlas, sehingga pelayanan tampil hangat, bersahaja, akrab dan tercipta hubungan yang harmonis baik internal maupun eksternal. Harapan kami melalui kegiatan pelatihan ini dapat meningkatkan kualitas para karyawan dalam memberikan pelayanan terbaiknya untuk kepuasan konsumen, yang pada akhirnya akan berdampak pada peningkatan kepuasan konsumen, produktivitas kerja perusahaan, operasional yang kondusif, hubungan harmonis disemua lini, hubungan harmonis antara perusahaan-karyawan-klien-supplier-pelanggan dan peningkatan omzet serta profit yang dapat diraih. 


\section{METODE PELAKSANAAN}

Tim di dalam pengabdian kepada masyarakat ini terdiri dari Masayu Endang Apriyanti, S.E, M.Pd sebagai ketua dan Fitriyah Puspita, S.E, M.Pd sebagai anggota, melakukan beberapa kali kunjungan dan pendekatan ke pihak perusahaan untuk membahas permasalahan yang dihadapi perusahaan mengenai kepuasan konsumen sehingga kami akan memberikan seminar pelatihan pada para karyawan dengan materi pembahasan yang berkenaan tentang pemberian solusi atas kebutuhan tersebut, dimana pada saat pelaksanaan kegiatan pengabdian kepada masyarakat, pembagian tugas nanti adalah kami akan memberikan wawasan, materi ilmu dan motivasi sesuai dengan latar belakang pendidikan dan pengalaman kerja yang kami miliki, membuka forum diskusi dan tanya jawab untuk membuka cakrawala beragam pola pikir para karyawan, khususnya untuk memberikan solusi dalam meningkatkan pelayanan terbaik mereka untuk melaksanakan konsep 3S (Senyum, Salam, Sapa) seoptimal mungkin guna kepuasan pelanggan secara menyeluruh.

Kualifikasi dari Tim ini yaitu Masayu Endang Apriyanti sebagai ketua adalah salah satu dosen pada prodi DKV yang mengampu mata kuliah yang terkait ekonomi, memiliki relevansi atas keilmuan dan latar belakang pendidikan ekonomi serta beberapa kali pengalaman bekerja sebelumnya (sebagai praktisi / staff didunia usaha pada beberapa perusahaan) yang berkaitan dengan manajemen Sumber Daya Manusia dan marketing, sehingga mampu menjelaskan dan memberikan pelatihan yang tepat untuk tema yang diangkat pada abdimas kali ini dan Fitriyah Puspita, S.E, M.Pd sebagai anggota adalah salah satu dosen prodi tekhnik informatika yang mengampu mata kuliah terkait ekonomi, latar belakang pendidikan ekonomi serta sampai saat ini masih aktif bekerja disalah satu bank swasta di jakarta, sehingga dapat memberikan wawasan dan contoh real studi kasus yang berhubungan dengan keadaan terbaru bagaimana sebaiknya operasional kegiatan yang didukung dengan pelayanan terbaik untuk pelanggan pada perusahaan yang bergerak dibidang perbankan.

Kami melakukan pengamatan, penjajakan dan pendekatan dengan mitra lalu kami menyusun isi materi penyuluhan dan pelatihan sebaik dan seefektif mungkin hingga pembuatan jadwal pelaksanaan pelatihan untuk karyawan sudah di mulai awal tahun 2018 dan karena faktor kendala yang ada, maka realitas dilakukannya pelaksanaan abdimas baru terwujud pada akhir bulan April 2018 dengan target sasaran adalah para karyawan dari perwakilan dua perusahaan mitra abdimas kami yang bergerak dibidang usaha stasiun pengisian bahan bakar umum yang berlokasi disekitar Bekasi.

\section{HASIL DAN PEMBAHASAN}

Sebelum kegiatan abdimas ini dilaksanakan, para karyawan masih banyak yang belum mengerti peran pentingnya mereka dalam memberikan pelayanan terbaik bagi setiap pelanggan yang datang, sehingga pada umumnya mereka masih banyak yang belum melaksanakan tugas pelayanan terhadap konsumen secara maksimal. Namun setelah kami berikan seminar pelatihan mengenai tema yang kami angkat ini, kami menyajikan teori tentang $3 \mathrm{~S}$, kami memberikan penyuluhan dan penjelasan secara gamblang pada mereka, Alhamdulillah mereka menjadi memahami secara mendalam tentang peran penting pelayanan terbaik yang harus mereka lakukan serta dampak negatifnya jika tidak dilaksanakan begitu juga bagaimana dampak positifnya jika mereka dapat laksanakan pelayanan terbaik semaksimal mungkin dan terbukti dengan respon 
aktif mereka dalam memperhatikan dan bertanya tentang banyak hal terkait kepuasan konsumen dan apa sebaiknya yang harus mereka lakukan.

Pada hari pelaksanaan kegiatan pengabdian kepada masyarakat pada bulan April 2017, dihadiri oleh perwakilan 45 karyawan dari 2 unit usaha kerja PT. Dharma Krida Satria dan PT. Tidie Pratama sebagai mitra abdimas kami kali ini, dimana kami sebagai tim abdimas memberikan seminar, penyuluhan, penjelasan dan pelatihan kepada para peserta mengenai pengertian dan pemahaman tentang konsep 3S (Senyum, Salam dan Sapa), apa manfaat yang didapat oleh orang yang bersangkutan (karyawan), antar para karyawan dengan partner kerjanya, antara karyawan dengan pihak perusahaan dan karyawan terhadap pelanggan, serta seberapa besar pengaruh pelaksanaan konsep $3 \mathrm{~S}$ tersebut dalam melayani setiap pelanggan yang datang dan melalui pelaksanaan seminar ini para peserta yang datang sangat terlihat antusias dalam memperhatikan penjelasan kami, terbukti mereka sangat fokus ketika mendengarkan materi yang disampaikan dan sangat kooperative saat sesi tanya jawab yang kami sediakan.

Kami berdua sebagai tim abdimas mempersiapkan segala kebutuhan alat-alat perlengkapan pelatihan melalui seminar dengan membawa mic dan sound system sendiri untuk memperjelas suara kami agar diskusi berjalan dengan kondusif dan semua dapat memahami secara detail mengenai pentingnya konsep $3 \mathrm{~S}$ ini dilaksanakan sepenuh hati agar pelayanan terbaik dapat tercipta secara optimal, lalu mereka dipersilahkan untuk menanyakan hal apa saja yang terjadi dilapangan yang bersinggungan antara pelanggan dengan operator SPBU lalu kami memberikan alternatif solusi jawaban atas pertanyaan kasus yang mereka hadapi. Setelah seminar ini, para karyawan baru benar-benar menyadari dan memahami betapa pentingnya konsep 3S dilaksanakan sepenuh hati, karena dampak positifnya bukan hanya terhadap pihak luar diri kita, melainkan sangat berpengaruh terhadap kedamaian didalam pribadi kita sendiri.

1. Banyak karyawan yang berpikiran bahwa bekerja hanyalah untuk mendapatkan bayaran (gaji) saja, padahal dimulai dari hal kecil seperti dengan melaksanakan $3 \mathrm{~S}$ selama melaksanakan pekerjaannya secara ikhlas, maka bukan hanya sejumlah nominal uang yang didapatkan, melainkan bernilai ibadah amal sholih karena berangkat dengan niat yang suci, lalu ia juga mendapatkan pahala bersedekah melalui senyuman, yang menimbulkan kebahagiaan didalam hati orang lain dan diri kita, lalu dengan salam dan sapa, menciptakan suasana yang konsudif penuh keridhoanNya melalui salam hangat yang selalu tersebar kepada semua pelanggan dan para klien.

2. Kami tim dosen berusaha maksimal untuk memberikan contoh real mengenai tipetipe karyawan dalam menghadapi pelanggan dengan beragam karakter yang dimilikinya, lalu berusaha memberikan solusi terbaik yang seharusnya dilakukan untuk mempertahankan pelanggan setia kita agar tidak pindah kelain hati (perusahaan lain).

3. Dalam sesi tanya jawab, kami membuka kesempatan seluasnya untuk semua karyawan yang ingin bertanya, mereka sangat antusias dengan respon positif dan mengajukan beberapa pertanyaan yang bisa dibahas serta dicari penyelesaiannya dalam sesi diskusi tanya jawab ini. 

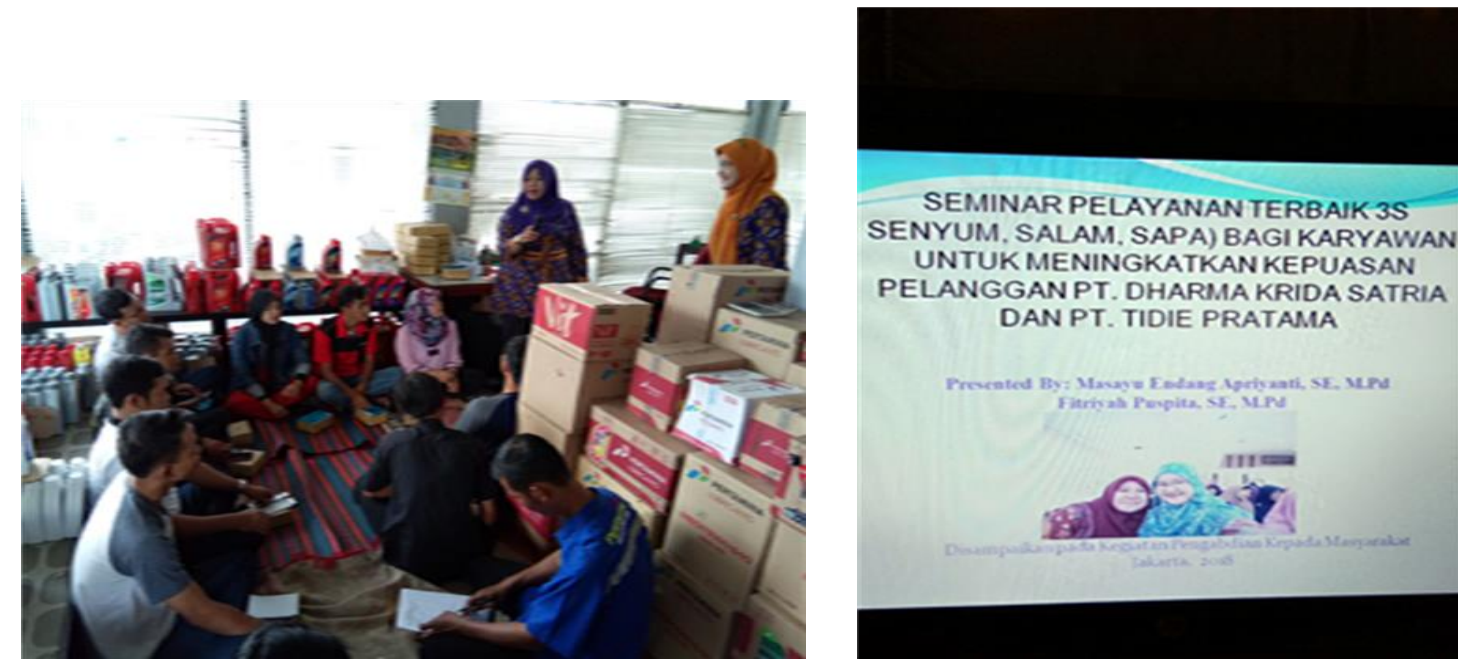

SEMINAR PELAYANAN TERBAIK $3 S$

SENYUM, SALAM, SAPA) BAGI KARYAWAN UNTUK MENINGKATKAN KEPUASAN

PELANGGAN PT. DHARMA KRIDA SATRIA DAN PT. TIDIE PRATAMA

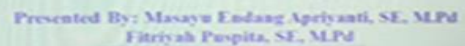
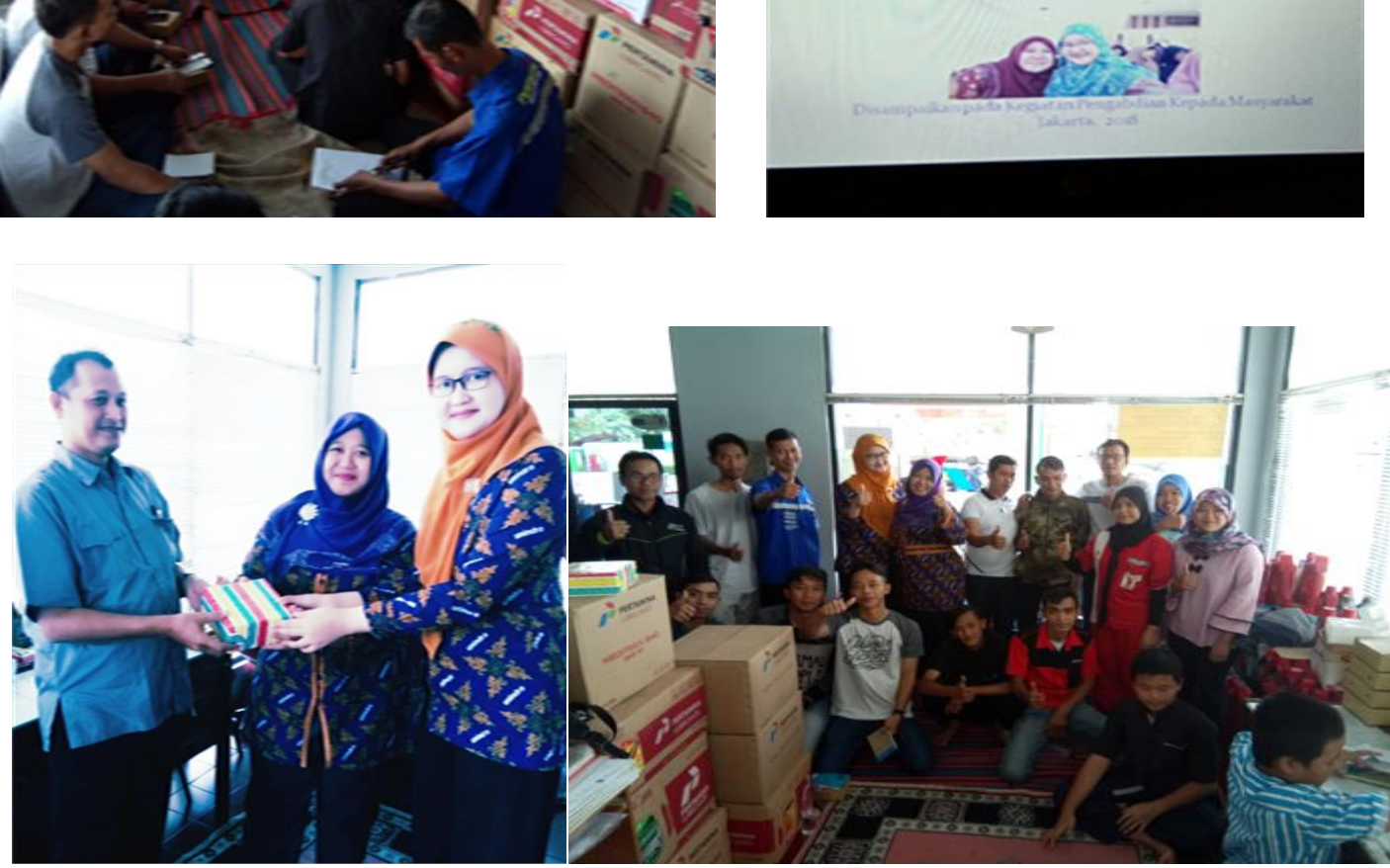

\section{SIMPULAN}

Dalam kegiatan Pengabdian Masyarakat Pelatihan Pelayanan 3 S (Senyum, Salam, Sapa) bagi karyawan untuk meningkatkan kepuasan pelanggan yang dilaksanakan pada PT. Dharma Krida Satria dan PT. Tidie Pratama yang telah kami laksanakan, memberikan simpulan bahwa kegiatan ini :

1. Jumlah karyawan sebagai peserta yang mengikuti penyuluhan dan pelatihan dalam abdimas ini dalam jumlah yang cukup sehingga mereka dapat mengerti dengan baik semua yang kami jelaskan dan kami berikan juga contoh studi kasus terkait $3 \mathrm{~S}$ yang dilakukan oleh perusahaan.

2. Kami sebagai Tim Dosen memberikan mereka note (buku tulis mini) dan pulpen agar mereka dapat menulis poin-poin penting yang kami sampaikan, juga mereka dapat menyusun pertanyaan yang akan diajukan kepada kami dalam sesi tanya jawab.

3. Penyuluhan dan pelatihan berjalan dengan baik dan seluruh peserta sangat antusias memperhatikan dan mengajukan pertanyaan pada sesi pertanyaan atas kasus atau masalah yang pernah mereka hadapi dengan konsumen, sehingga kami dapat memberikan alternatif jawaban sebagai solusi dimasa depan jika yang bersangkutan bertemu dangan pelanggan yang modelnya sama seperti itu. 
4. Dalam sesi tanya jawab, maka terlihat banyak hal-hal yang sangat memungkinkan terjadi didalam pelaksanaan 3S sepanjang pekerjaan yang mereka lakukan, dalam hal ini berkaitan dengan melayani konsumen agar mereka puas.

5. Tim Dosen memberikan beberapa contoh gambaran konsep 3S yang dilakukan para karyawan dibeberapa perusahaan dan Bank yang tentunya dengan komposisi yang berbeda dalam pelaksanaan $3 \mathrm{~S}$ akan memberikan hasil kepuasan pelanggan yang berbeda juga, dimana semakin baik dan sepenuh hati melaksanakan 3S sepanjang jam kerjanya, maka akan semakin tinggi pula tingkat kepuasan yang didapatkan pelanggan atas pelayanan yang diterimanya.

\section{DAFTAR PUSTAKA}

Agustian, A.G. (2000). Kecerdasan Emosi dan Spiritual. Jakarta : Arga.

Anthony, R., Vijay G., (2005). Sistem Pengendalian Manajemen, buku 1. Jakarta : PT. Salemba Emban Patria.

Argene, R. (2003). Strategi Menjadi Wiraswasta Handal. Jakarta : PT. Restu Agung.

Charney, C. (1998). The Instant Manager - Rahasia menjadi manajer yang handal. Batam : Interaksara.

Djajendra. (2017). Pelayanan Pelanggan Terbaik Dimulai Dari Dalam Diri Yang Positif Dan Rendah Hati. Jakarta : PT. Djajendra service Exelence.

Elwood S. Buffa, E.S., Sarin, R.K. (2002), Manajemen Operasi / Produksi Modern, Jakarta : Bina Rupa Aksara.

Soegoto, E.S. (2014). Entrepreneurship : Menjadi Pebisnis Ulung, Jakarta : PT. Elex Media Komputindo. 